Theories \& Applications, the International Edition

Printed Version: (ISSN 2090-5262)

Online Version: (ISSN 2090-5270)

November 2013, Volume 3, No. 3 Pages (1 - 10)

\title{
The Extent of Physical Education Teachers' Possession of Technological Competencies and Practicing It in Second Phase from Basic Education
}

\author{
Noor Taha Ibrahim Hussain*
}

\section{Introduction}

$\mathrm{I}^{\mathrm{n}}$ n of globalization, communications, technical and technology era there is an increased need for constantly developing teacher. There is global consensus that teacher is the main pillar in any education system. Without trained intelligent teacher; aware of his role in a holistic manner; no education system can achieve its goals. As era change teacher needs change and so teacher must cope with era changes. (Mustafa Abdul Sami Mohammed, 1999:p108) (Ali Ben Saleh Elkhabty, 2003:p8)

Second Conference of Arabs Ministers of Education in Jordan (2000) recommended that teacher should possess the skills to use modern technologies, expansion of use of information and training teachers and raise their efficiency through modern technology. (ALECSO, 2000 p7)

"Mohamed Saad, and Makarem Helmy" (2001) argue that success of educational process in achieving its objectives depends on several factors, the most important of it is teacher role as a participant in planning, preparation, organization and evaluation of educational content and curricula, so the issue of teacher preparation is one of the vitally important issues in the field of education. It is not possible to make change without creating suitable environment; this can be only done through educational technology which allow teacher to use his educational experience about how to use different sources of technological knowledge. (Makarim Helmy Abu Hrjh et al, 2001: pp 24, 147)

The researcher in the opinion that this era is witnessing rapid and successive developments;

* Lecturer, Curricula and Teaching Methods Department, Faculty of Physical Education, Mansoura University, Egypt. so it is no longer enough for teacher to master scientific content for subject he teach, simply because it change and accumulate on ongoing. Teacher is no longer knowledge transferor; there are new technologies which is more fast and capable than him. As the most important characteristic of this period is the new means and methods. Teacher's new role is to guide students and motivate them to learn and search, select, test and use new knowledge. So teacher should be familiar with using innovative media, how to build educational programs and its various situation, design educational programs in a manner which consistent with learners' needs, capacities and characteristics, and teacher's role in this strategy is the guider, which helps learner in setting goals, and make different education sources available for earner. In this regard Mustafa Badran et al (1999) argue that through using educational technology, teacher can account for individual differences between learners, give them experiences suit them which in turn increases their positivity and raise their enthusiasm and help them to think positive, and eventually lead them to teaching quality; i.e. using education technology by teacher achieves various educational purposes. (Mustafa Badran et al, 1999: pp 19-24)

Mustafa Abdel Samie (1999, p57), Atef ElSayed. (2000, p26), and Shrum and Lamb (2002, p7) all agreed that technology is a basic necessity for educational systems development and improve various aspects of teaching and learning. Systems concept means that it is a set of parts with interactive relationships between them aims to achieve an object or more. Systems approach is the base of educational technology. Using this approach in education field led to change the perception of modern technological means like computer, educational television, closed television circuit and 
educational films from being just teaching aids to elements in information technology system and training within the framework public education system.

Makarim Helmy Abu Hrjh et al (2001, p7) indicates that physical education in terms of being information, laws and skills must be mastered, is in need to exploit all progress scientific means from techniques and methods in order that facilitate work of teacher and learner, to reach the desired goals, where means used in education became inadequate, do not achieve the desired progress in sport skills learning and the educational process skill.

Salahuddin Khaled Mohammed (2004, p7) adds that teachers training on using IT education labs is the most important link in integrated system to develop these labs. It is not the matter of buying hardware, but to train teachers on use of these devices. Providing schools with different devices would do nothing without trained efficient teacher in this area, and has necessary experience and competencies of educational technology. It is not possible to succeed in controlling the machine, if teachers who use it do not know the objective of its use, and how to use; therefore in-service teacher training on education technology is necessary to help them improve their performance, and enable them to effectively employ educational technology, and develop their positive attitudes towards it, as they can cope new developments in this area, and facilitate efforts to develop education, all of which helps to renew and promote educational process.

Due to information revolution and technological progress teacher's role is no longer limited to the transfer knowledge, teach lessons to students; explain lesson and perform applied models, correct technical errors. the only source of knowledge, but teacher's role in information technology is the planner, designer, evaluator of educational process, where application of scientific thought and modern technological methods in designing educational plans and programs a dictated necessity by current phase, and that needs to update in thought and strategies based.( Anwar El-Abed, 1985: pp4351)

In light of this teacher's new role; availability of education technological competencies within teacher became a necessity; that is to allow teacher to efficiently and effectively perform his important role in physical teaching education. Within this competencies: knowledge of education objectives, knowledge of students in terms of their circumstances and their education levels, mastery of the curriculum and its objectives and content, teaching methods, realize the importance of good planning, ability to organize lesson. Physical education teacher needs to be competent for student assessment learning in main aspects namely motor, physical, knowledge, emotional aspects. Also competencies related to technological devices and audio-visual aids usage, employment of surrounding environment, and other competencies which he shares with other subjects' teachers. Therefore it has become necessary to reconsider nature of teacher preparation programs in light of technological developments and contemporary challenges. (Yaakoub Nashwan, 2009: p215)

As educational technological competencies are important for teachers in service and student teacher in education colleges, therefore many studies have addressed it e.g.: Saeed Bin Rashid El-Sunaidi (2000), Syed Mohammad Sengy (2001), Ali Mohammed Saleh (2002), Fathi Yusuf Mohamed (2003), Ali El- Dairi and Emad AL-Bataineh (2004), Ihsan bin Mohammed Kensara (2007), Hassan Ali Ahmed (2010) and their findings noted the importance of availability of a set of educational technological competencies within teachers of different specialties and they are in desperate need to practice these skills for development of the educational process.

Determining of education competency is very important matter because these knowledge allow Faculties of physical education to draw philosophy outline for preparing student teachers, in addition this help to evaluate teacher preparation programs and their performance before starting work. Hence competencies should be the cornerstone of these programs which in turn make learning and training more efficient and effective. In this sense, the most important of these skills at present time is teachers competency in information technology and therefore students training on this competency make the student 
teacher in faculties of Physical Education in line with modern era requirements. To the researcher's knowledge there is no previous study exposed to determine list of technological competencies should be possessed by teacher as most of the studies and researches have focused on necessity of technology using and not on how to use and the necessary skills to do so.

Mohamed Saad, Mustafa Al-Sayeh (2004, p166), mention that there are several types of information technology that can be used in selftraining for future teachers in teaching physical education, and information technology types with varying capacities in delivering information provide capacity and more comprehensive opportunities to extend teacher's knowledge aspects.

Through researcher work and her practical experience in supervising students' field training and contact with physical education teachers she noted that there are large number of physical education teachers lack some educational technological competencies, especially in using and producing educational communication means, which raised researcher interest to determine teachers' technological competencies and their practicing extent within the scope of education development which is a national requirement

\section{Research objectives}

Identify educational technologies physical education teachers and define the extent of using them.

\section{Research Queries}

1. What is the possession extent for educational technological competencies within physical education teachers?

2. What is practicing extent for educational technological competencies within physical education teachers?

3. Is there a relationship between possession extent for educational technological competencies within physical education teachers and their practicing for it?

\section{Research Methodology}

Researcher used descriptive survey approach due to its relevance for current study nature.

\section{Research Society}

Research society represented in (351) physical education teachers, in boys preparatory

schools, Education Directorate, Dakahlia Governorate.

\section{Research Sample}

Researcher selected the sample randomly from research society in second semester of the academic year 2011/2012, research sample totaled to (200) physical educational teacher represent (56.98\%) of research society, also (30) teachers selected randomly as pilot sample to standardize (ensuring validity - reliability) of study questionnaire.

\section{Results and Discussion}

\section{First Query}

What is the possession extent for educational technological competencies within physical education teachers?

\section{Teaching and educational material design:}

Physical Education teachers' possession rate of competencies of Teaching and educational material design was in high level and ranged between $(6.67 \%-67.22 \%)$.

Researcher returns this result to the nature of physical education teachers work and their possession of teaching skills and professional competence and necessary steps to design education in terms of plan preparation, setting objectives and link it with activities, evaluation, taking into account learners characteristics when formulating these objectives and develop strategies per specific criteria. Teacher to succeed in his work, he must be aware of these competencies in order to be able to make effective education.

This result is in agreement with study results of: Saeed Bin Rashid El-Sunaidi (2000), Fathi Yusuf Mohamed (2003), Ali El-Dairi and Emad AL-Bataineh (2004), Ihsan bin Mohammed Kensara (2007), Hassan Ali Ahmed (2010).

\section{Selection of educational techniques:}

Physical Education teachers' possession rate of competencies of Selection of educational techniques was in average level and ranged between $(7.78 \%-55.56 \%)$. 
Researcher returns this result to the fact that selection criteria for educational techniques must come before its use, so the selection process of appropriate educational should follow accurate technical rules and standards to ensure achieving purposes which it selected for; therefore teacher should be aware to great extent about the importance of rules and standards for selecting educational techniques and that selection skills can be owned easily because it revolves around the general understanding of selection process for anything,

This result is in agreement with study results of: Saeed Bin Rashid El-Sunaidi (2000), Hassan Ali Ahmed (2010).

\section{Effective usage of educational techniques:}

Physical Education teachers' possession rate of competencies of Effective usage of educational techniques was in weak level and ranged between $(5.56 \%-66.67 \%)$.

Researcher returns this result to the fact that physical education teachers depend on order teaching method (demonstration) and do not realize the importance of using educational techniques and essential role it plays in the teaching-learning process.

This result is in consistent with what mentioned by Makarim Helmy Abu Hrjh et al (2001, p145) that the success of educational process in achieving its objectives depends on several factors, most important of it is teacher role as a participant in planning, preparation, organization and evaluation of educational content and curricula, so the issue of teacher preparation is one of the vitally important issues in the field of education. It is not possible to make change without creating suitable environment; this can be only done through educational technology which allow teacher to use his educational experience about how to use different sources of technological knowledge.

\section{Scientific equipment operating and maintenance:}

Physical Education teachers' possession rate of competencies of Scientific equipment operating and maintenance was in weak level and ranged between $(2.78 \%-88.89 \%)$.

Researcher returns this result to the fact that physical education teachers are not qualifying for these devices during their study in physical education faculties, in addition to the scarcity of educational devices in governmental schools, and if found not activated; but placed in laboratories, as well as there is no coordination between physical education teachers and supervisors specialists to provide such a service,

This result is in agreement with study results of: Saeed Bin Rashid El-Sunaidi (2000), Ali ElDairi and Emad AL-Bataineh (2004), Ihsan bin Mohammed Kensara (2007), Hassan Ali Ahmed (2010).

In this regard Shrum and Lamb (2002, p7)argue that using technologies in education is a necessity and that new system concepts require supplying graduates from schools and universities with set of competencies differ than that required I traditional system

\section{Educational programs and materials production:}

Physical Education teachers' possession rate of competencies of Educational programs and materials production was in weak level and ranged between $(0 \%-67.22 \%)$.

Researcher returns to non availability of training courses about these materials production, and they need a relatively large time to produce which increases the burden of teachers. This also could be due to study sample perception that producing educational materials and programs is not their direct specialty, but it is specialty of educational means supervisors.

Ali El-Dairi, Imad Al-Batayneh (2004, p17), Ihsan bin Mohammed Kensara (2007, p22) study results concluded that: beside huge expenditure on technological equipments in schools and universities, should be parallel expenditure on preparing and training students to deal with these equipments in design, production, using, and evaluating as it is educational technology system, and technological competencies are within the most important competencies nowadays

\section{Evaluation:}

Physical Education teachers' possession rate of competencies of Evaluation was in weak level and ranged between $(7.78 \%-43.89 \%)$. 
Researcher returns this result to the fact that many physical education teachers convinced that evaluation during and after the lesson is not important, and their interest only with teaching and learning students motor skills for team and individual sports, and if some of them care with evaluation process they focus on level of motor skills acquisition only

This result is in agreement with study results of: Fathi Yusuf Mohamed (2003), Hassan Ali Ahmed (2010).

\section{Second query}

What is practicing extent for educational technological competencies within physical education teachers?

\section{Teaching and educational material design:}

Physical Education teachers' practicing rate of competencies of Teaching and educational material design was in average level and ranged between $(0 \%-50 \%)$.

Researcher returns this result to the fact that syllabus must be implemented in a specific time and according to predetermined plan, and the lack of sufficient time to determine objectives and skills necessary to begin learning, as well as the lack of time to analyze learners characteristics, as well as many of physical education teachers do not implement physical education lesson as it should be.

\section{Selection of educational techniques:}

Physical Education teachers' practicing rate of competencies of Selection of educational techniques was in weak level and ranged between $(8.33 \%-45.56 \%)$.

Researcher returns this result to the fact that physical education teacher is not a technical supervisor to select materials and devices, this is an administration not teachers matter, in addition to lack of opportunity for teachers and learners to participate in selection committees for educational techniques.

\section{Effective usage of educational techniques:}

Physical Education teachers' practicing rate of competencies of Effective usage of educational techniques was in weak level and ranged between $(0 \%-31.1 \%)$.
Researcher explains this result by lack of refinement teachers after graduation, they are not updating themselves with the modern in educational skills education technology, and large numbers of students in classes, shortage of teachers in schools, in addition to academic works that teachers should do such as meetings, and supervision and guidance. in this regard Mohamed Saad and Mustafa El-Sayeh argue that teachers ability in information employment must be raised, and should therefore provide information environment with its scientific content, dissemination of information knowledge, and that teacher must be fullyprepared in all aspects, professional, academic and cultural.

This result is in agreement with study results of: Pamela(2000), Holt(2002), Hazem Abdul Muhsin Muhammad (2003), Lada et. al. (2004), $\mathrm{Yu} \mathrm{Ku}$, Hopper \& Igoe(2006), Reda Mostafa Helal (2008)

This result is in line with Mohamed Saad Zaghloul, Mustafa Al-Sayeh (2004) argument that teachers abilities in using information should be improved, so it is necessary to provide informational environment, and prepare teachers in all aspects: professional, academic and cultural

\section{Scientific equipment operating and maintenance}

Physical Education teachers' practicing rate of competencies of Scientific equipment operating and maintenance was in weak level and ranged between $(0 \%-21.11 \%)$.

Researcher returns this result to availability of specialists who operate such devices and instruments, researcher also suggests that care must be given to prepare the student teacher and refer to the importance of identifying a list of competencies required by them, and the need to reconsider education system to comply with educational technology requirements. In this regard Mesuet (2000), Holt (2002) emphasize on the necessity to prepare student teacher in technological side and adopting an integrated educational program.

This result is in agreement with study results of: Pamela (2000), Ali Mohammed Saleh (2002), Hazem Abdul Muhsin Muhammad (2003), Hassan Ali Ahmed (2010), Lada, et., Al. (2004), 
Salem bin Muslim Al-Kandi (2006), and $\mathrm{Yu} \mathrm{Ku}$ , Hopper \& Igoe (2006)

\section{Educational programs and materials production:}

Physical Education teachers' practicing rate of competencies of Educational programs and materials production was in weak level and ranged between $(0 \%-43.89 \%)$.

Researcher returns this result to the fact that possession of these competencies requires great time and effort, in addition to that production of these materials needs to acquire special skills may not be available for many physical education teachers, This also could be due to study sample perception that producing educational materials and programs is not their direct specialty, but it is specialty of educational means supervisors.

This result is in agreement with study results of: Saeed Bin Rashid El-Sunaidi (2000), Ali ElDairi and Emad AL-Bataineh (2004), Ihsan bin Mohammed Kensara (2007), Hassan Ali Ahmed (2010).

In this regard Makarem Helmy Abu Hrjh, Mohamed Saad Zaghloul (2000, p34) argue that professional preparation for physical education teacher is not suit work requirement, and that teachers have not enough knowledge in modern technological methods in teaching physical education.

\section{Evaluation:}

Physical Education teachers' practicing rate of competencies of Evaluation was in weak level and ranged between (1.11\%- 21.67\%).

Researcher explain this result by the fact that Evaluation process need to design different types and variety of motor and cognitive achievement tests to measure learning level, and this needs pre, between and final tests, in addition to the fact that teachers' focus only on final evaluation. This result is in agreement with study results of Hassan Ali Ahmed (2010).

Bedor El-Mutawa, Suhair Bedier Mosa (2006) mention that most of physical education teacher ignore evaluation part for learner's various aspects; this may be due to that teacher do not have the knowledge about cognitive, skill and motor tests to measure learning level, so these tests should be made available,

\section{Third query}

\section{Is there a relationship between possession extent for educational technological competencies within physical education teachers and their practicing for it?}

Correlation coefficient between possession extent for educational technological competencies within physical education teachers and their practicing for it was (0.197), which indicates presence of statistically significant correlation at level of 0.05 , which indicates the strength and direction of the relationship between degree of possession and degree of practice, researcher returns this result to that when competencies are available within physical education teachers degree of practicing increase, and vice versa. Results of current study show that both possession and practicing of educational technological competencies were weak. In this regard Mumbi (2000)), Pamela (2000) argue that modern techniques must be used in theoretical and practical fields and the importance of using these techniques in physical education, the need to prepare and train teachers in service and students teachers pre-service on the use of computers and dealing with technology, and the need to provide computers for them and they should know how to use them.

Makarem Helmy Abu Hrjh, et al (2001, p53) mention that educational competencies contribute in the process of teacher preparing in faculties of physical education and train him in skills and abilities required during educational situations; Preparing based on competencies have effective power in pushing educational processing. Competencies approach have great interest within educational establishment around the world which proof it is the best solution for preparing teachers in reality situation.

Mumbi (2000) and Pamela (2000) stress on the necessity of using modern techniques in both theoretical and applied fields, importance of using these techniques in sport, necessity of train teachers on service and student/teachers before service on using computers and deal with technological equipments, and necessity of supplying computers to schools. 
I. Physical education teacher highly possessed (14) educational technology competencies with percentage of $(\mathbf{1 6 . 8 7 \%})$

\section{Teaching and educational material design:}

- Organizing teaching content according to behavioral objects.

- Determine general objectives of prepared and designed subject.

- Set various activities to account for individual differences between learners.

\section{Selection of educational techniques:}

- Considering cost and effectiveness in selecting educational technology means

- Considering learners' characteristics in selecting educational technology means.

- Selecting educational technology means suit teaching method.

\section{Effective usage of educational techniques:}

- Preparing learners setting places in front of demonstrating screen.

- Ensuring spatial and technical requirement for watching and listening in healthy position with clarity for all learners.

- Considering learner's number while selecting educational technology means.

4. Scientific equipment operating and maintenance

- Ability to operate audio recorders

5. Educational programs and materials production:

- Ability to use photographic cameras

- Writing on slides with special pens

6. Evaluation

- Design various types to measure learning level.

- Get benefit from feedback to improve educational technology means. And teaching methods.
II. Physical education teacher averagely possessed (12) educational technology competencies with percentage of $(14.46 \%)$

1. Teaching and educational material design:

- Wording behavioral objects relate to design educational means and programs.

- Find alternative means suitable to educational situation.

- Analyze education curricula to determine its requirements from technological tools and equipments

\section{Selection of educational techniques:}

- Considering suitability of educational to concept displayed like to be moveable when introducing motor skill.

- Considering safety and security in selecting educational technology means.

- Defining problems facing teacher when selecting educational technology means.

3. Effective usage of educational techniques:

- Ensuring clarity of educational means to all learners.

- Exploring educational materials to ensure it suits lesson objectives

- Helping and supervising learners during activities.

4. Scientific equipment operating and maintenance

- Ability to operate and use video to display educational program.

5. Educational programs and materials production:

- Produce printed text using computer

6. Evaluation

- Determine problems facing using technological means in educational situations.

- Get benefit from feedback to improve educational technology means. And teaching methods

III. Physical education teacher very weakly possess (57) with percentage of $(68.67 \%)$ 
IV. Physical education teacher highly practice - from their points of view - possess (5)) educational technology competencies with percentage of $(6.02 \%)$

\section{Teaching and educational material design:}

- Organizing teaching content according to behavioral objects..

- Determine general objectives of prepared and designed subject.

\section{Selection of educational techniques:}

- Considering cost and effectiveness in selecting educational technology means

- Considering safety and security in selecting educational technology means.

3. Effective usage of educational techniques:

- None

4. Scientific equipment operating and maintenance

- None.

5. Educational programs and materials production:

- Produce printed text using computer

6. Evaluation

- None.

V. Physical education teacher averagely practice - from their points of view - possess (6) educational technology competencies with percentage of $(\mathbf{7 . 2 3 \%})$

1. Teaching and educational material design:

- None

2. Selection of educational techniques:

- Considering applicability in educational situation cost and effectiveness in selecting educational technology means

3. Effective usage of educational techniques:

- Ensuring spatial and technical requirement for watching and listening in healthy position with clarity for all learners.

4. Scientific equipment operating and maintenance

- Ability to operate and use video camera.
5. Educational programs and materials production:

- Copying cassette tapes

\section{Evaluation}

- Get benefit from feedback to improve educational technology means. And teaching methods.

- Design various types to measure learning level.

\section{Recommendations}

1. Getting benefit of educational technological competencies list when appoint physical education teachers in public and private schools.

2. There is necessity to use during preparation and training of student teachers in faculties of Physical Education.

3. To provide and create appropriate educational environment that stimulates teachers to acquire, own and practice educational technological competencies and this should be essential quality requirement in educational institutions.

4. Create special departments for education technology in faculties of Physical Education.

5. Adding educational technological competencies curriculum in post-graduate curricula.

6. Incorporate training on educational technology as a prerequisite in development, preparation and rehabilitation program for physical education teachers to be assigned in different jobs.

7. Further studies to be carried out in the field of educational technology competencies

\section{References}

1. Ali El-Dairi, Imad Al-Batayneh (2004): "Educational competencies and its level of practicing within field training students in Faculty of Physical Education", VIII International Scientific Conference for Sport and Physical Education Science, vol. I, Faculty of Physical Education for Men, Alexandria University. (in Arabic Language) 
2. Ali Ben Saleh Elkhabty (2003): Development prospective for self development for teacher, Life time learning model for teachers, research paper presented to 11th conference for educational work leaders, Riyadh. (in Arabic Language)

3. Ali Mohammed Saleh (2002): "Developing a list of performance and professional competencies associated with motor growth for kindergarten teachers ", Master Thesis, Faculty of Physical Education for Men, Helwan University. (In Arabic Language)

4. Anwar El-Abed (1985): educational technology, its development, concept, and role in improving teaching, education technology, issue (16), 8th year, the Arab Organization for Education, Culture and Science. (in Arabic language)

5. Arab League Educational, Cultural and Scientific Organization (ALECSO) (2000): Second Conference of Arabs Ministers of Education, (Future school) Jordan. (in Arabic language)

6. Atef El-Sayed. (2000): Education information technology and using computers and video in teaching and learning, Ramadan Press, Alexandria.(in Arabic Language)

7. Bedor El-Mutawa, Suhair Bedier Mosa (2006): physical education curricula and teaching methods, Dar ElKetab, Cairo. (in Arabic language)

8. Crawford, C.,willis, D., proceedings of society for Information technology and teacher Education International Conference,(pp.,:1691 1696).

9. Fathi Yusuf Mohamed (2003): "Evaluating performance efficiency of physical education teacher at first phase of basic education in Alexandria", Ph.D. thesis, Faculty of Physical Education for Men, Alexandria University. (In Arabic Language)

10. Hassan Ali Ahmed (2010): "Appreciation Degree for importance of educational technological competencies within science teachers to improve their professional performance," Journal of University of Damascus, Syria, Volume (26), number (3). (in Arabic language)
11. Hazem Abdul Muhsin Muhammad (2003): Analytical study of the use of educational technology in teaching physical education in UAE, Journal of sport Sciences, Volume (15), Faculty of Physical Education, Minya. University. (in Arabic language)

12. Holt ,J., (2002) : The determination of computer competencies needed by classroom teachers , ERIC document reproduction service, No.Ed 410955.

13. Ihsan bin Mohammed Kensara (2007): The extent of Staff members of Umm Al-Qura university possession of technological competencies and practicing it in and difficulties they face, Educational and Psychological Research series, Educational and Psychological Research Institute, , Umm Al Qura University, Saudi Arabia. (in Arabic language)

14. Lada,S.,(2004): Including Technology in Instructional Programs.

15. Makarem Helmy Abu Hrjh, Mohamed Saad Zaghloul (2000): Physical Education Curricula's problems (diagnosis and treatment), Dar El Ketab, Cairo. (in Arabic language)

16. Makarem Helmy Abu Hrjh, Mohamed Saad Zaghloul, Hany Said Abdel-Moneim (2001): Technology and its methods in physical education, Dar El Ketab, Cairo. (in Arabic language)

17. Meust ,D.,(2000) : Examination of technology integration into an elementary teacher education program on university experience, $\mathrm{PhD}$, Ohio university, available at : (http://www.lip-umi.com/dissration/pervewall/19980406),9-6-2003.

18. Mohamed Saad Zaghloul, Mustafa Al-Sayeh (2004): technology development and rehabilitation of physical education teacher, Dar El-Wafaa, Alexandria. (in Arabic language)

19. Mumbi ,K.,(2000): The impact of laptop computers on pre service teacher practicum experiences , $\mathrm{PhD}$, college of education , Ohio university, available at : (htt://www.lipumi.com/dissertation/pervew-all/9980418)

20. Mustafa Abdul Sami Mohammed (1999): Education Technology - Arabic Studies, Dar ElKetab, Cairo.(in Arabic language) 
21. Mustafa Badran, Ibrahim Mutaoea, Mohamed Mohamed Attia (1999): Teaching aids, the Anglo-Egyptian Library, Cairo. (in Arabic language)

22. Pamela,L., (2000) : How pre service teacher incorporate technology into lesson during their practice teaching experience, an intrinsic case study , PhD , the university of Nebraska Lincoln available at : http :// www.lipumi.com/disserations/prevew-all/9977024, 9-6.

23. Reda Mostafa Helal (2008): "Evaluation of Educational Techniques in physical education curricula, preparatory schools," Journal of Physical Education Research, Volume (42), issue (79), Faculty of Physical Education for Men Boys, Zagazig University. (in Arabic language)

24. Saeed bin Rashid El-Sunaidy (2000): "Educational technical competencies and practicing extent within faculty of education staff members, Sultan Qaboos University" Master thesis, Yarmouk University, Irbid, Jordan. (in Arabic language)

25. Salahuddin Khaled Mohammed (2004): Designing training program based on educational modules for development of teachers competencies in use of multimedia labs, Master, Faculty of Girls, Ain Shams University. (in Arabic Language)

26. Salem bin Muslim Al-Kandi (2006): "The reality of using modern educational techniques and the difficulties faced it in public schools in Sultanate of Oman", Faculty of Education Journal, Sultan Qaboos University, Oman. (in Arabic language)

27. Sayed Mohammed Sengy (2001): "a program to develop some teaching competencies of Islamic religion education teachers in preparatory phase", $\mathrm{PhD}$ thesis, Faculty of Education, Banha, Zagazig University. (In Arabic Language)

28. Schrum, L., \& Lamb, T.,(2002): Computer Network SAS instructional and collaborative Distance learning Environment. Available at: ( http:// www. Att. Com / learning Network / virtuelacade/ Success2.HTML2003.

29. Yaakoub Nashwan (2009): The new in science education, 3rd ed., Dar Al-Furqan, Jordan. (in Arabic language)

30. Yu Ku, H., Hopper,L., \& Igoe,A.,(2006): Perecptions of teachers technology competency skills in Arizona," In Crawford, C., willis, D., proceedings of society for Information technology and teacher Education International Conference,(pp.,:1691 - 1696). 